\title{
Holocene environmental dynamics of south-eastern Brazil recorded in laminated sediments of Lago Aleixo
}

\author{
Dirk Enters • Hermann Behling • \\ Christoph Mayr • Lydie Dupont • \\ Bernd Zolitschka
}

Received: 26 January 2009/Accepted: 11 December 2009/Published online: 31 December 2009

(C) Springer Science+Business Media B.V. 2009

\begin{abstract}
Environmental changes of the last 9,300 years were reconstructed by geochemical and pollen analyses of a 14-m-long, laminated sediment core from Lago Aleixo, south-eastern Brazil. Fossil pollen assemblages indicate open savannah vegetation (campo cerrado) and gallery forests until approximately $6,900 \mathrm{cal}$. BP. During that time, siderite laminae were deposited under anoxic conditions at the lake bottom. Then, increased rainfall and a shorter annual dry period allowed gallery forests and semideciduous forests to expand, leading to more closed cerrado vegetation. High-intensity rainfall events during this period are recorded as peaks in $\mathrm{K}$ and $\mathrm{Ti}$ concentrations. The sediment facies during this period
\end{abstract}

D. Enters $(\bowtie) \cdot$ B. Zolitschka

GEOPOLAR, Institute of Geography, University

of Bremen, 28359 Bremen, Germany

e-mail: enters@uni-bremen.de

D. Enters

EDYTEM UMR 5204, Université de Savoie,

73376 Le Bourget du Lac, France

Present Address:

D. Enters

Lower Saxony Institute for Historical Coastal Research,

Viktoriastr. 26/28, 26382 Wilhelmshaven, Germany

H. Behling

Department of Palynology and Climate Dynamics,

Albrecht-von-Haller-Institute for Plant Sciences,

University of Göttingen, Untere Karspüle 2,

37073 Göttingen, Germany consists of alternating layers of diatoms and minerogenic matter. $\mathrm{C} / \mathrm{N}$ ratios imply that algae and perhaps soils, too, were the main contributors to sediment organic matter. Biogenic silica and $\delta^{13} \mathrm{C}_{\text {org variations }}$ indicate increasing primary productivity, which was related to higher nutrient flux from intensified leaching of soils, as shown by rising $\mathrm{K} / \mathrm{Al}$ ratios. Around 800 cal. BP, a closed, semi-deciduous forest developed under present-day climate conditions. Slope stabilization diminished erosion processes in the catchment and caused reduced input of minerogenic matter into the basin. Human impact is evident in the topmost homogeneous sediments, as removal of the stabilizing forest cover amplified soil erosion. The continuous trend to more humid conditions during

C. Mayr

GeoBio-Center and Department of Earth and

Environmental Sciences, Richard-Wagner-Str. 10,

80333 Munich, Germany

Present Address:

C. Mayr

Institute of Geography, University of Erlangen-

Nuremberg, Kochstr. 4/4, 91054 Erlangen, Germany

L. Dupont

MARUM-Center for Marine Environmental Sciences,

University of Bremen, P.O. Box 330440,

28334 Bremen, Germany 
the Holocene probably reflects increased influence of the Amazon Basin as a moisture source. We conclude that the Lago Aleixo sediment archive was a sensitive recorder of environmental dynamics in tropical South America, which were mainly controlled by changes in precipitation patterns.

Keywords Holocene - Pollen analysis ·

Sedimentology · Geochemistry · Vegetation history · SE Brazil

\section{Introduction}

South-eastern Brazil is a key area for the reconstruction of past vegetation and climate dynamics in tropical South America because of the diverse range of biomes, i.e. tropical Atlantic rainforests and semideciduous forest to the east and savannah vegetation (cerrado) to the west (Olson et al. 2001). The distribution of biomes is largely controlled by the length of the dry season and the amount of annual precipitation (Behling 2003), which in turn are influenced by monsoon-like changes in convective precipitation related to the migration of the (oceanic) Intertropical Convergence Zone (ITCZ), the South Atlantic Convergence Zone (SACZ), Antarctic cold fronts, and ENSO variability (Garreaud et al. 2009).

Perturbation of the global climate system could therefore result in changes of the regional precipitation regime, which would consequently affect the distribution of these biomes. In this context, paleoenvironmental studies are important tools to understand and improve model results of modern and future vegetation and climate changes (Salazar et al. 2007). Such studies also serve to assess the vulnerability and resilience of these ecosystems, which are currently severely affected by non-sustainable human land-use practices. Finally, these studies also provide a scientific basis to assess questions of biodiversity conservation and restoration strategies (Willis et al. 2007).

Multi-proxy datasets in paleoenvironmental studies generally yield a more consistent and precise picture of environmental changes than does analysis of only a single variable. Sedimentological, mineralogical and geochemical variables add valuable information to pollen-inferred vegetation changes in the tropics. They provide insights into changes in geomorphological processes and limnological conditions, both of which reflect the prevailing climate-controlled hydrological regime from different perspectives (Behling and Costa 2000; Sifeddine et al. 2001; Rodrigues-Filho et al. 2002). However, relatively few paleoenvironmental reconstructions in the tropical lowlands of southeastern Brazil have combined palynological records with high-resolution geochemical data, with most studies based solely on pollen analysis (De Oliveira 1992; Ledru et al. 1994; Behling 1995, 2003; Parizzi et al. 1998).

In this study, we used fossil pollen spectra, elemental composition, and stable carbon isotopes to examine an approximately 14-m-long lake sediment core recovered from Lago Aleixo, south-eastern Brazil. Our aim was to determine the sensitivity of both the regional vegetation and the geomorphologic system to climate change. A general trend to wetter conditions in the study area during the Holocene was inferred from pollen records of nearby Lago do Pires (Behling 1995) and Lagoa Nova (Behling 2003). These studies indicate that savannah vegetation (cerrado) and riverine gallery forests covered the area from $c a \cdot 11,200$ to $6,300 \mathrm{cal}$. BP, reflecting dry conditions. With higher precipitation between 6,300 and 2,900 cal. BP, the gallery forests expanded, while hilltops were still covered by cerrado. From 2,900 to $900 \mathrm{cal}$. BP, the open cerrado vegetation changed to closed tree canopy (cerradão), reflecting a further increase in precipitation and a shorter dry period. During the latest Holocene, which has been relatively wet compared to earlier times, the presence of a closed semi-deciduous forest is indicative of modern climate conditions. Our specific objectives were to investigate how these changes are reflected in records of other sediment proxies and to reveal how geomorphologic processes changed in response to the inferred climate change.

\section{Study site}

Lago Aleixo (17 $59^{\prime} 16^{\prime \prime} \mathrm{S}, 42^{\circ} 07^{\prime} 08^{\prime \prime} \mathrm{W}, 390 \mathrm{~m}$ asl) is a shallow (maximum water depth $5 \mathrm{~m}$ ) lake with a surface area of about $1.3 \mathrm{~km}^{2}$ and a relatively large catchment (Fig. 1). It is situated in the foothills of the Serra da Noruega (maximum elevations between 500 and $700 \mathrm{~m}$ asl) of south-eastern Brazil, $\sim 250 \mathrm{~km}$ 


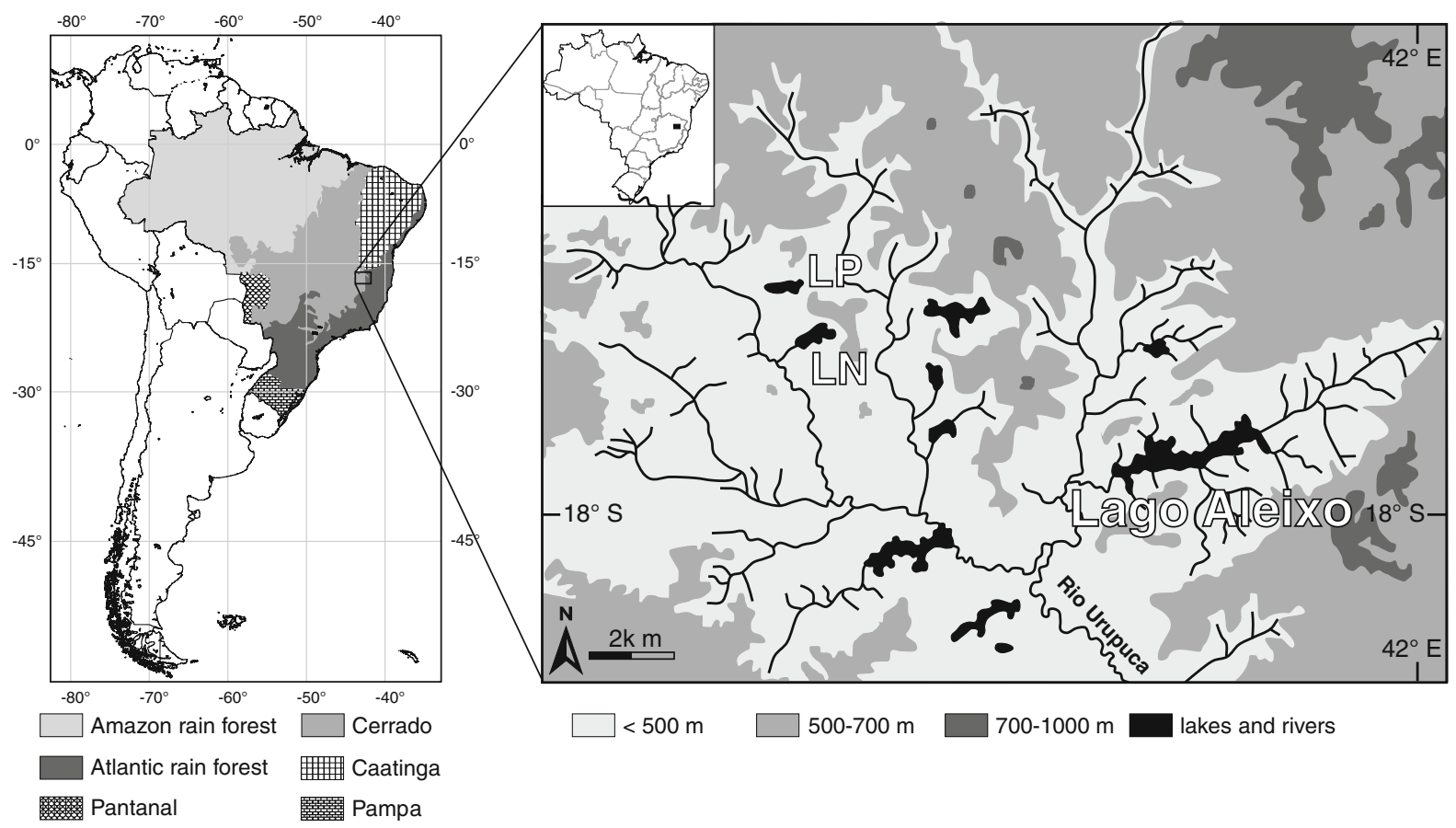

Fig. 1 Major biomes of Brazil (left), based on IBGE (1993) and location of Lago Aleixo (right). The dashed black line indicates the seasonal migration of the ITCZ. Also shown are

inland from the Atlantic Ocean. The origin of the lake is still uncertain, but it may have been formed during the last glacial period by rapid accumulation of alluvial fan sediments from a tributary river or by a landslide that dammed the parent valley floor, as has been described for other lakes in adjacent regions of SE Brazil (Parizzi et al. 1998; Rodrigues-Filho et al. 2002). No limnological data for Lago Aleixo are currently available. Studies of similar valley lakes along the Rio Doce, $\sim 170 \mathrm{~km}$ southwest of the study site, show that these lakes are warm monomictic, with a short period of isothermy in winter (June-July) and a period of pronounced thermal stratification during the warm rainy season, from October to April (Tundisi and Saijo 1997).

The bedrock at the study site is composed of crystalline rocks of the East Brazilian Shield (migmatite-granulitic and granite-greenstone, Rodrigues-Filho and Müller 1999) which is covered by up to $30 \mathrm{~m}$ of lateritic soils. Mineralogy of the lateritic cover is dominated by quartz and weathering products such as kaolinite and gibbsite, with some goethite and hematite (Rodrigues-Filho et al. 2002). Present-day climate conditions, with annual rainfall the location of previously studied Lago Pires (LP, Behling 1995) and Lagoa Nova (LN, Behling 2003)

of about 1,250 mm, mean annual air temperature of $22.5^{\circ} \mathrm{C}$ and a 4-month dry season (Nimer 1989), support a 20-30-m-tall, tropical semi-deciduous forest. Intensive deforestation for charcoal production and pastures during the last century has almost completely destroyed the original vegetation. Small stands of relict original forests remain on hilltops, but are disturbed by selective logging and fire (Pereira et al. 2007). Today, widespread secondary, degraded grasslands and agricultural fields are threatened by soil erosion.

\section{Materials and methods}

Core recovery and storage

In August 1993, a 14-m-long sediment core was retrieved from the central part of Lago Aleixo, at a water depth of $5 \mathrm{~m}$, using a modified Livingstone piston corer. Sealed core sections were stored under dark and cool conditions until they were analyzed in spring 2004. Minor shrinkage through desiccation was identified by comparison with X-radiographs that 
were taken soon after coring. The lower two core sections show disturbances caused by coring procedures. These disturbed parts of the sequence were considered gaps in the sediment record.

\section{Dating}

The age-depth model is based on five radiocarbon samples, one bulk sample and four samples of plant remains (Table 1), dated at Beta Analytic (USA) and at the Poznań Radiocarbon Laboratory, Poland, respectively. Radiocarbon dates were calibrated with Calib 5.01 (Stuiver and Reimer 1993) and the Intcal04 calibration dataset (Reimer et al. 2004). The age-depth model was calculated using mixedeffect regression as described by Heegaard et al. (2005).

\section{Pollen analysis}

Standard pollen preparation techniques were applied, including acetolysis and treatment with hydrofluoric acid (Faegri and Iversen 1993). Pollen samples were counted to a total of 300 pollen grains, except for a few samples with low pollen content that were counted to a total of 200 pollen grains. The pollen sum excludes aquatic taxa and fern spores. Six ecological groups are distinguished and illustrated in percentage pollen diagrams: (1) forest trees and shrubs-mainly Moraceae/Urticaceae, Melastomataceae, Cecropia, Acalypha, Celtis, Alchornea, Myrsine, Trema-type, Schinus-Litharea-type and Vitistype; (2) cerrado trees-Curatella, Byrsonima, Stryphenodendron and Copaifera-type; (3) Palms (Atlantic rainforest taxa)-Euterpe/Genoma-type; (4) herbs and grasses-Poaceae, Cyperaceae, Ambrosia-type and Asteraceae; (5) aquatics-Typha and Ludwigia and (6) ferns.
Unconstrained multivariate ordination was applied to summarize the major vegetational patterns in the pollen stratigraphy using PC-ORD (McCune and Mefford 1999). An initial detrended correspondence analysis (DCA) gave a relatively small maximum gradient length of 1.1, and thus principal component analysis (PCA), using a variance-covariance cross product matrix, was chosen as the ordination method (Lepš and Šmilauer 2003). Percentage data for 21 pollen types were used and transformed to the arcsine of the square root prior to ordination analysis. For comparison, the same analysis was performed on the pollen dataset of nearby Lago Pires (77 pollen samples and 32 pollen types, Behling 1995). A new age-depth model was calculated for the Lago Pires record, using mixed-effect regression (Heegaard et al. 2005) and the available ${ }^{14} \mathrm{C}$ dates.

Sedimentological analyses

Magnetic susceptibility (Bartington MS2F sensor) and $\mathrm{X}$-ray fluorescence of major elements (Avaatech XRF core scanner, $\mathrm{Rh}$ tube at $10 \mathrm{kV}, 300 \mu \mathrm{A}, 30 \mathrm{~s}$ live time) were measured continuously at $1-\mathrm{cm}$ increments on split core surfaces. To illustrate long-term changes, median values and 10- and 90-percentiles of the XRF dataset were calculated for 500-year intervals.

A total of 82 volumetric sediment samples of $1 \mathrm{~cm}^{3}$ were taken using plastic syringes. These samples were freeze-dried and homogenized using an agate mortar and pestle. The concentrations of total carbon (TC) and total nitrogen $(\mathrm{TN})$ were determined on untreated samples through combustion in an elemental analyzer (EuroEA, Eurovector). Total organic carbon (TOC) was analyzed with the same instrument after removal of carbonates by successive addition of 3 and $20 \%$ $\mathrm{HCl}$ at $80^{\circ} \mathrm{C}$. Biogenic silica was analyzed by alkaline leaching according to Müller and Schneider (1993).

Table 1 Radiocarbon dates from the Lago Aleixo sediment record

\begin{tabular}{lllclrrr}
\hline & Lab. no. & Sample & Depth $(\mathrm{cm})$ & Sample description & ${ }^{14} \mathrm{C}$ age & $\delta^{13} \mathrm{C}(\%)$ & cal. BP $(1 \sigma)$ \\
\hline 1. & Poz-8491 & ALE 0430 & 333 & Leaf fragments & $940 \pm 30$ & $-29 \pm 0.6$ & $797-916$ \\
2. & Poz-8492 & ALE 07 26 & 629 & Leaf fragments & $2,150 \pm 30$ & $-27.8 \pm 0.8$ & $2,066-2,298$ \\
3. & Beta-67173 & ALE 10 82-86 & 984 & Bulk & $4,860 \pm 90$ & -27.3 & $5,474-5,711$ \\
4. & Poz-8407 & ALE 11 65 & 1,071 & Leaf fragments & $5,460 \pm 40$ & $-24.5 \pm 0.2$ & $6,213-6,298$ \\
5. & Poz-8464 & ALE 14 44 & 1,344 & Leaf fragments & $7,960 \pm 50$ & $-26.7 \pm 0.4$ & $8,725-8,978$ \\
\hline
\end{tabular}


Carbon isotope ratios of bulk organic matter $\left(\delta^{13} \mathrm{C}_{\text {org }}\right)$ were determined on 30 samples that were decalcified for $6 \mathrm{~h}$ with $\mathrm{HCl}(5 \%)$ at $50^{\circ} \mathrm{C}$ in a water bath. Analyses were done using a mass spectrometer (Isoprime, Micromass) linked to the elemental analyzer (EuroEA, Eurovector). Isotope ratios are reported as $\delta$ values in \%o according to the equation

$\delta^{13} \mathrm{C}_{\text {org }}=\left(R_{\text {sample }} / R_{\mathrm{VPDB}}-1\right) \times 1,000$,

where $R$ is the measured ratio of ${ }^{13} \mathrm{C} /{ }^{12} \mathrm{C}$ of the sample and the international standard Vienna-PeeDee-Belemnite (VPDB), respectively. On selected sections of the sediment record, bulk mineralogy was determined by X-ray diffraction on randomly oriented powder mounts of ground samples using a Philips X'Pert Pro MD equipped with an X'Celerator Detector-Array (CuK $\alpha$ radiation, $45 \mathrm{kV}, 40 \mathrm{~mA})$. In addition, the microstratigraphy of laminated units was studied on several large-format thin sections.

\section{Results}

Sediment description and mineralogy

From 1,394 to $\sim 1,000 \mathrm{~cm}$ core depth, the sediment consists of $\sim 1 \mathrm{~mm}$-thick, dark brown to yellowbrown laminae, with occasional intercalated grayish clay bands (Fig. 2b). Thin sections and XRD analyses reveal that the laminations are composed of alternating layers of authigenic siderite $\left(\mathrm{Fe}[\mathrm{II}] \mathrm{CO}_{3}\right)$ layers rich in biogenic opal, and amorphous organic matter, with abundant ostracod shells. Above 1,000 cm core depth, the lithology changes gradually to alternating sequences of yellow-brown, diatom-rich laminae and intercalated greyish, graded minerogenic deposits (Fig. 2a), characterised by large mica plates (up to $1 \mathrm{~mm}$ in diameter) concentrated in the basal part. The laminations become increasingly diffuse towards the top. The uppermost $80 \mathrm{~cm}$ of the sediment record consists of homogeneous, diatom-rich mud with occasional clay bands. XRD analyses reveal the presence of kaolinite throughout the sequence. No conclusive evidence of gibbsite, hematite or goethite was found in the diffractograms. Secondary pyrite $\left(\mathrm{Fe}[\mathrm{II}] \mathrm{S}_{2}\right)$ concretions are abundant in all units, whereas only a few aggregates of vivianite $\left(\mathrm{Fe}[\mathrm{II}]_{3}\right.$ $\left.\left(\mathrm{PO}_{4}\right)_{2} \cdot 8 \mathrm{H}_{2} \mathrm{O}\right)$ were found macroscopically.
Chronology

All radiocarbon dates are in stratigraphic order. The age-depth model gives an extrapolated age of 9,300 cal. BP for the oldest retrieved sediments (Fig. 3). Sedimentation rates in the lower part of the record are around $1 \mathrm{~mm} / \mathrm{a}$. After ca. 2,200 cal. BP, sedimentation rates increase, reaching maximum values of $\sim 4 \mathrm{~mm} \mathrm{a}^{-1}$ at the top of the record.

Pollen analysis

More than 150 pollen taxa were found in the sediment record and four local pollen zones (A-I to A-IV) were differentiated, based on major changes in pollen assemblages. The most important pollen types (percentage values $>2 \%$ in at least 3 samples) of the main ecological groups are given in Fig. 4. A-I ( $c a$. 9,300-6,900 cal. BP) is characterised by high percentages of Poaceae and Curatella americana. Notably, the abundance of pollen types typical of forest species (Moraceae/Urticaceae, Cecropia, Acalypha, Celtis, Alchornea) is high and almost no aquatic pollen types are found in this period. After 6,900 cal. BP, grass pollen decreases and Curatella becomes rare in A-II, while Styphenodendron occurs in higher abundance. The percentages of forest pollen types increase slightly and the Euterpe/Geonoma-type becomes more common after around 6,000 cal. BP (Fig. 4). Typha is found relatively frequently in this pollen zone. At around $800 \mathrm{cal}$. BP (A-III) herb pollen decreases markedly and Styphenodendron becomes very rare. Forest taxa have their highest pollen percentages and the pollen types of Euterpe/ Geonoma as well as Vitis become frequent. A-IV is only represented in the sample from $14 \mathrm{~cm}$ depth and is characterised by a large increase of herb pollen and a related decrease in forest species, as well as by a synchronous increase in aquatic pollen, mainly Typha.

The first PCA axis of the Lage Aleixo dataset explained $30 \%$ of the total variance (Lago Pires: $48 \%$ ). Because pollen types of cerrado species and Poaceae have high negative scores on axis 1, whereas forest species and pollen type of Euterpe/ Geonoma show positive scores, we interpret the underlying environmental factor of axis 1 as moisture gradient. 
Fig. 2 Flatbed scans $(\mathbf{a}, \mathbf{c})$ and microscopic images $(\mathbf{b}, \mathbf{d})$ of thin sections typical for the two major lithological units: a $878 \mathrm{~cm}$ sediment depth, normal light: dark colours represent silt/clay laminae, light colours are layers consisting of diatom frustules; b sharp boundary between a diatom (lower 2/ 3 of the image) and clay sublamina, the black spheres in the center represent framboidal pyrite; c $1,351 \mathrm{~cm}$ sediment depth, normal and polarized light: siderite layers are visible under polarized light as light laminae; d close-up showing the bedding of a dark siderite lamina above an obstacle (presumably a plant fragment). The scale bar is $5 \mathrm{~mm}$ in a, c, $100 \mu \mathrm{m}$ in $\mathbf{b}$ and $500 \mu \mathrm{m}$ in $\mathbf{d}$
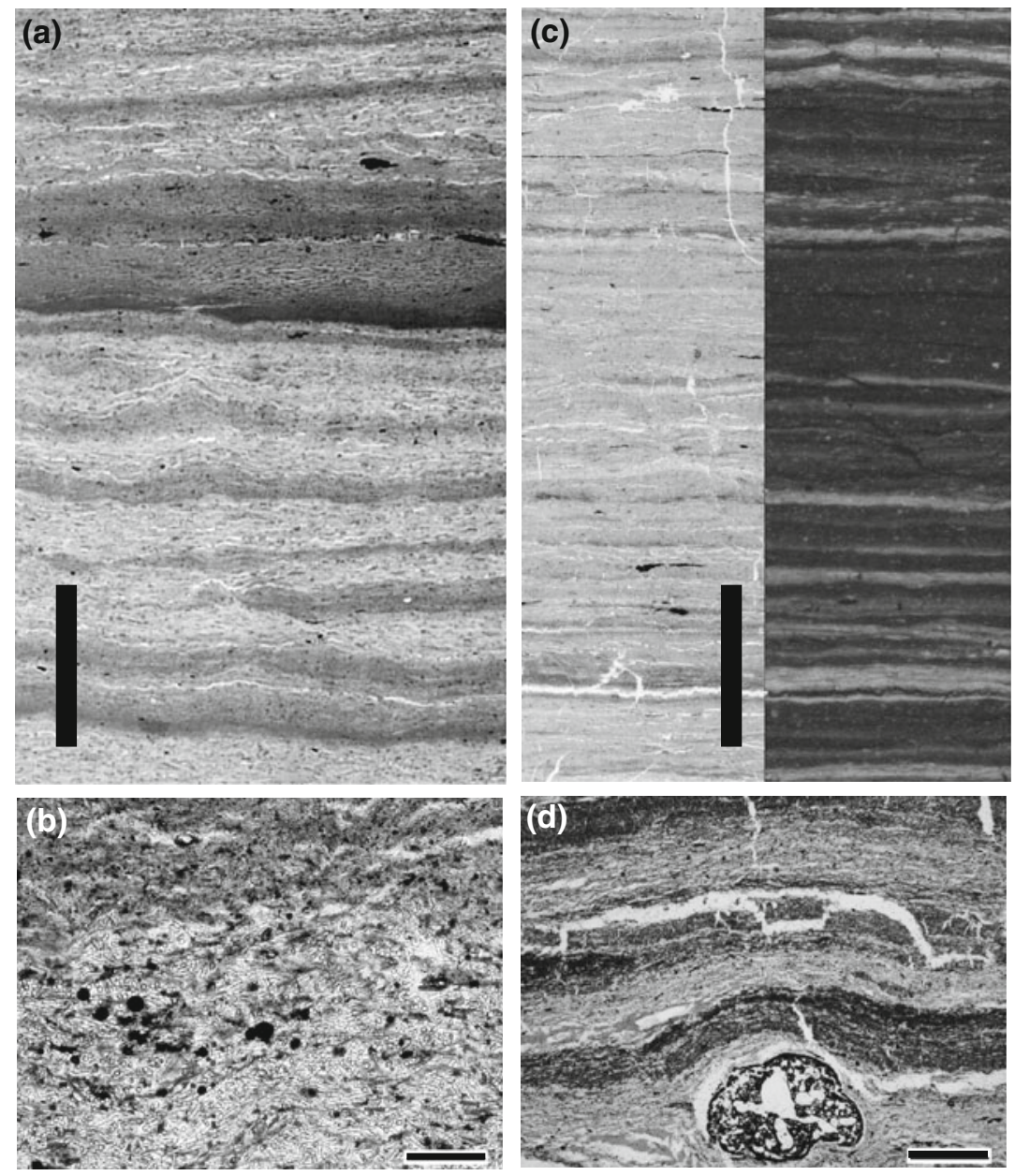

Sedimentological variables

The record of magnetic susceptibility (MS) shows average values of about $100 \times 10^{-6}$ SI units in the basal part of the core, which decrease to mean values $<25 \times 10^{-6}$ SI units starting around 5,000 cal. BP (Fig. 3). There are two periods, 7,500-5,200 and 2,900-1,600 cal. BP, during which the MS record shows prominent peaks, and at the top of the record MS reaches maximum values of $>400 \times 10^{-6} \mathrm{SI}$ units. The records of $\mathrm{K}$ and $\mathrm{Ti}$ ratio show highfrequency variability for the period between about 7,000 and 1,000 cal. BP, followed by relatively uniform values for the last 1,000 years. Similar to the MS record, the youngest sediments are characterised by increases in $\mathrm{K}$ and $\mathrm{Ti}$. The total organic carbon content increases from around $4 \mathrm{wt} \%$ in the oldest sediments to maximum values of $\sim 15 \mathrm{wt} \%$ between 2,000 and 1,000 cal. BP, and decreases considerably to $2.5 \mathrm{wt} \%$ at the top. In contrast, $\mathrm{C} / \mathrm{N}$ ratios exhibit relatively stable values of around 10 , which are typical of authigenic production in lakes (Meyers and Lallier-Vergès 1999), with some fluctuations between 7,500 and 4,500 cal. BP and at the top of the record. The concentration of total inorganic carbon (TIC) ranges between 0.8 and $2.7 \mathrm{wt} \%$, prior to $8,000 \mathrm{cal}$. BP, then fluctuates frequently between 0 and $1 \mathrm{wt} \%$ until $\sim 400 \mathrm{cal}$. BP. TIC is negligible in the uppermost sediments. Biogenic silica (BiSi) shows several distinct peaks within the sediment profile. Relatively low values occur until $c a$. 5,000 cal. BP, after which there are several periods when BiSi concentration reaches $>15 \mathrm{wt} \%$. The record of $\delta^{13} \mathrm{C}_{\text {org }}$ shows minimal values of about $-30 \%$ in the lower, siderite-rich part of the profile. Despite some marked excursions, there is generally 


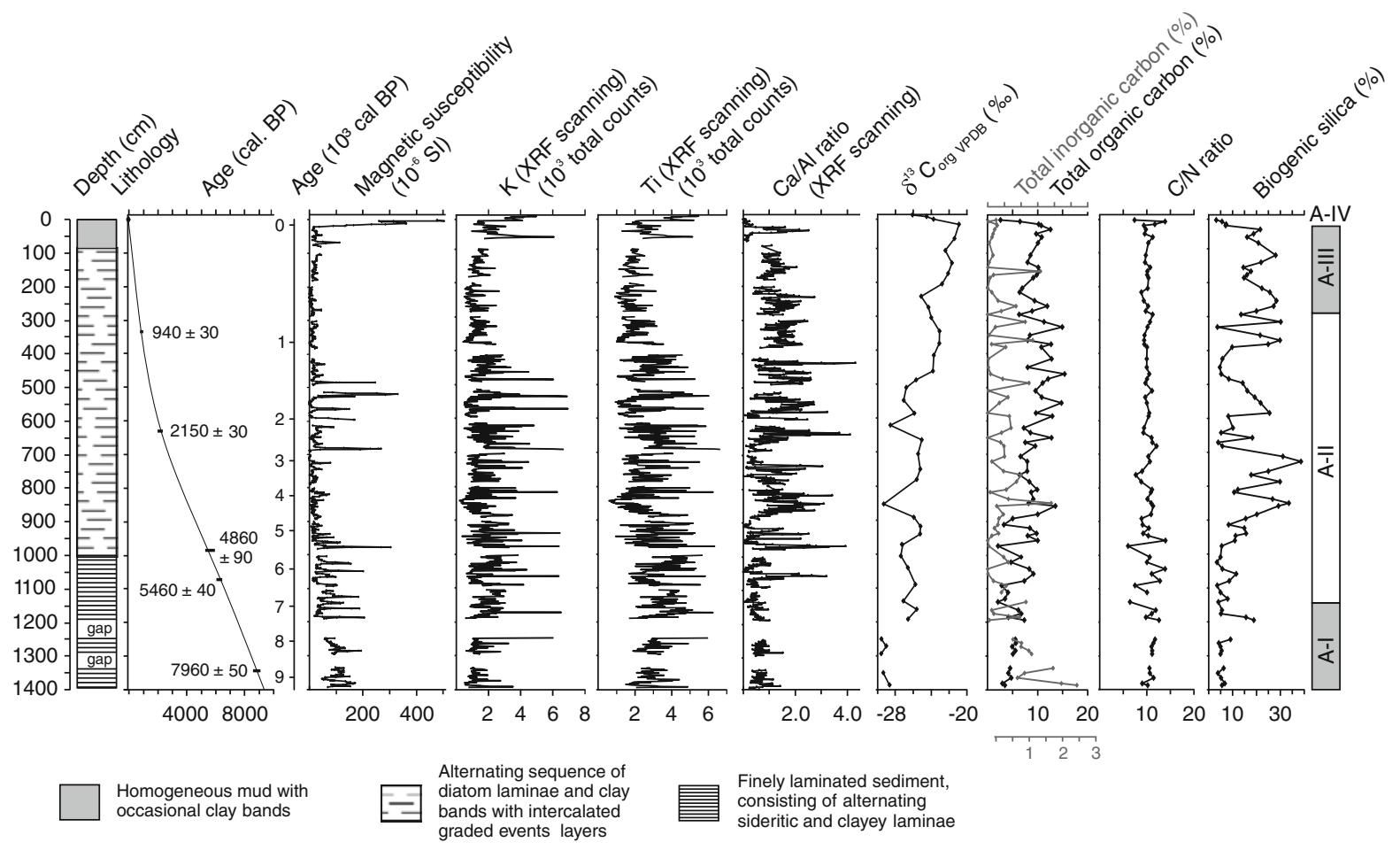

Fig. 3 Multi-proxy results of sedimentological analyses of the Lago Aleixo record including lithology, age-depth relationship, summarized pollen data and geochemical results. The assigned local pollen zones (AI-IV, Fig. 4) are indicated to the right. In the age-depth model, depth and calibrated 2-sigma ranges of radiocarbon samples are indicated together with their uncalibrated ages

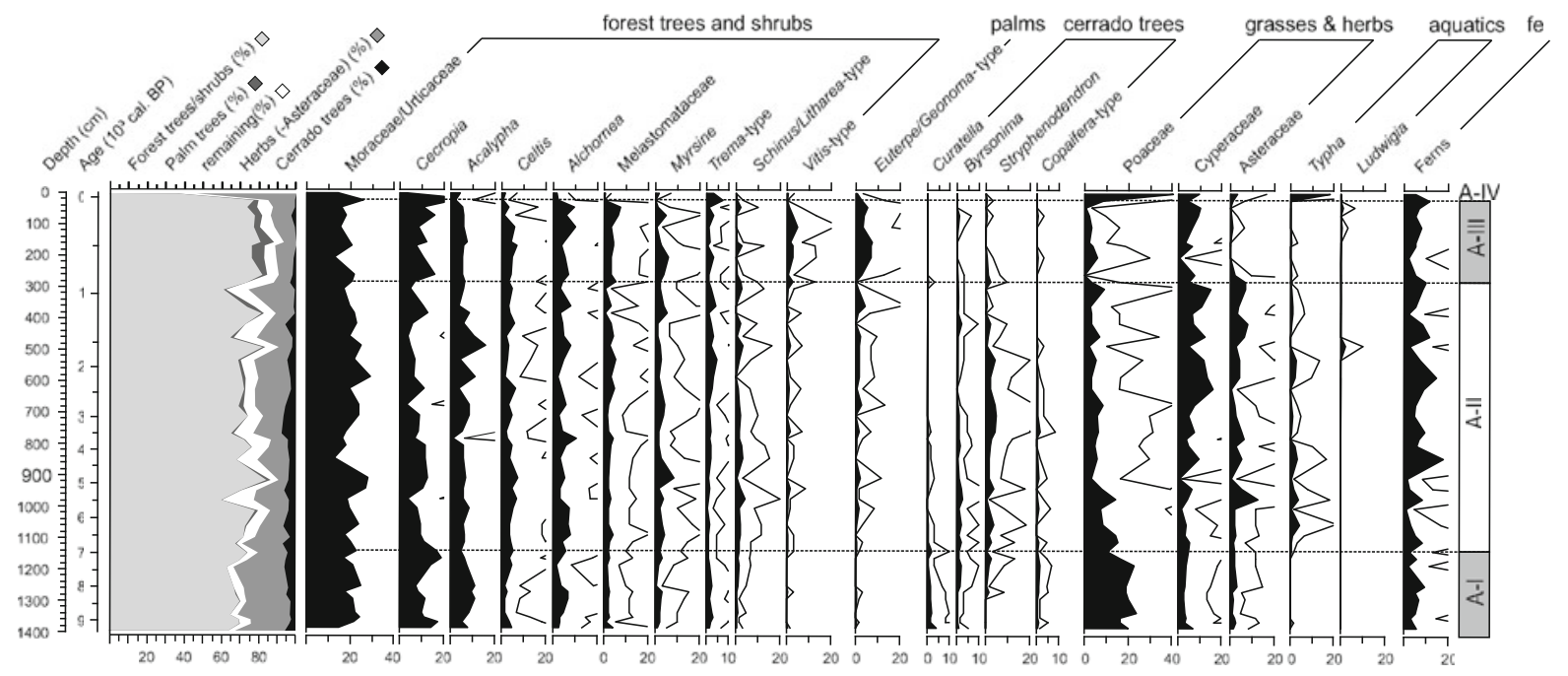

Fig. 4 Percentage pollen diagram and local pollen zones (AIIV) of Lago Aleixo. Out of the 150 classified pollen and spore types only the pollen types ( $>2 \%$ abundance) which can be assigned to ecological groups (see text for details) are shown. The thin black line denotes a $5 \times$ exaggeration of the percentage data 
an increase in $\delta^{13} \mathrm{C}_{\text {org }}$ values from almost $-26 \%$ at 7,500 cal. BP to $-21 \%$ in the youngest sediments. Within uppermost samples, there is a drop to values of $-26 \%$.

Long-term changes in sediment composition are particularly evident in the decreasing $\mathrm{Fe}$ and $\mathrm{Fe} / \mathrm{Al}$ ratio and in the steadily increasing $\mathrm{K} / \mathrm{Al}$ ratio towards the top of the core (Fig. 5). With the exception of a period around $3,000 \mathrm{cal}$. $\mathrm{BP}, \mathrm{Ca} / \mathrm{Al}$ ratios show generally higher and more variable values during the last 4,000 years than in older sediments.

\section{Discussion}

Vegetation history and inferred climate conditions

The occurrence of Curatella americana, an insectpollinated cerrado tree (Felfili and Fagg 2007), together with Byrsonima, Copaifera-type and abundant Poaceae, reflects open savannah vegetation in A-I. The relatively high percentages of forest taxa in this period suggest that gallery forests and semideciduous forest vegetation existed around the lake and along its tributaries, whereas upland areas were likely covered with campo cerrado. This vegetation pattern is indicative of dry climate conditions with low annual precipitation and a dry season of about 6 months, as previously interpreted in the records of Lago do Pires (Behling 1995) and Lagoa Nova (Behling 2003).

Although Curatella americana disappears gradually in A-II $(6,900-800$ cal. BP), the increased presence of Styphenodendron, another cerrado species, still suggests a relatively dry climate. However, the appearance of Atlantic rainforest taxa such as the palms of the Euterpe/Geonoma-type indicates slightly moister conditions. This apparent contradiction is explained by higher annual precipitation and a shorter dry season of about 5 months (Behling 1995, 2003), allowing the gallery forests and semi-deciduous forest to expand into higher regions while the area of campo cerrado decreased and changed to a more closed cerrado, probably to cerrado, sensu stricto or cerradão (Behling 1995).

The changes in pollen assemblages in A-III indicate a further shift to wetter conditions. Cerrado vegetation disappeared in the region and a closed semi-deciduous forest covered the catchment area almost completely. This is indicative of modern climate conditions, with a dry season of around 4 months. A-IV reflects vegetation changes by
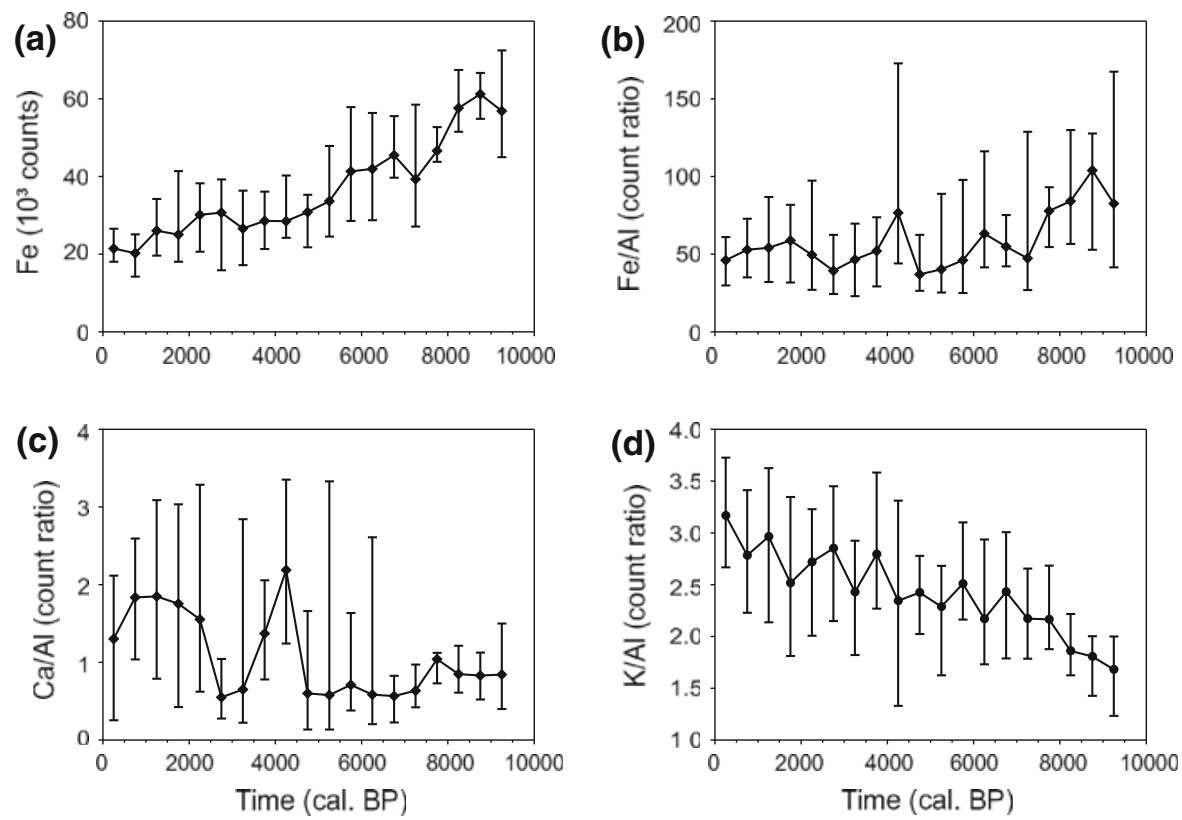

Fig. 5 Median values of selected XRF parameters calculated for 500-year time slices. Error bars denote 10- and 90-percentiles, respectively 
anthropogenic deforestation starting during the last century. High percentages of Typha in this zone probably reflect a higher flux of nutrients into the lake, improved light conditions, and an increase in shallow-water habitats around the inflows through sedimentation of eroded soil.

The trend to more humid conditions during the Holocene, inferred from the lacustrine record of Lago Aleixo, is explained by an intensification and/or southward shift of the Amazon convection centre (Bush and Silman 2004) or, alternatively, increased influence of South Atlantic cyclones as an extratropical moisture source. However, a slight shift to more negative $\delta^{18} \mathrm{O}$ values in speleothem records of south-eastern Brazil (Cruz et al. 2006) indicates tropical air masses of the Amazon Basin as dominant sources of precipitation. Similarly, the expansion of the Amazon rainforest during the last 3,000 years in eastern Bolivia has been explained by an increased seasonal latitudinal migration of the ITCZ (Mayle et al. 2000). Evidence for increasingly wetter conditions is also found in the high Andes, where lake levels rose considerably during the middle and late Holocene (Seltzer et al. 2000).

Contrasting paleoenvironmental reconstructions from other parts of Brazil, such as the central Brazilian highlands, emphasize the need for a regional network of paleoenvironmental archives. Pollen profiles from Lagoa dos Olhos and Lagoa da Serra Negra show that during most of the Holocene the study area was occupied by a mosaic of cerrado and semi-deciduous forest (De Oliveira 1992). Ledru et al. (1994) deduced from a nearby pollen record at Salitre that Araucaria forests, which established at the beginning of the Holocene, were replaced after ca. 9,500 cal. BP by semi-deciduous forest under warmer and drier climate conditions. At around 4,500 cal. BP at Salitre, the climate turned moister and reached present-day conditions. A climatic transition from dry to moister conditions, at around 9,500 cal. BP, is reported from Lago Silvana, located $\sim 180 \mathrm{~km}$ to the south (Rodrigues-Filho et al. 2002). At that time, dry conditions presumably occurred around Lago Aleixo.

\section{Sedimentological variables}

The sedimentological analyses supplement environmental changes inferred from the pollen record. The sediment data point to relatively stable environmental conditions prior to $c a$. 7,000 cal. BP (approximately A-I). Low values of biogenic silica suggest low lake productivity and, possibly, intensified dissolution and recycling of biogenic silica. The lack of large fluctuations in $\mathrm{K}$ and $\mathrm{Ti}$ concentrations (Fig. 3), which are indicative of terrestrial minerogenic input, implies less erosive rainfall events. This is also confirmed by the microstratigraphy, as detrital layers were relatively rare. The higher values of magnetic susceptibility are caused by siderite, a paramagnetic mineral, and probably do not indicate increased influx of clastic material into the lake. The occurrence of siderite in conspicuous laminae suggests synsedimentary formation at the sediment-water interface, probably within or beneath microbial mats, under anoxic conditions and with abundant dissolved $\mathrm{Fe}^{2+}$ and high concentrations of $\mathrm{pCO}_{2}$ (Brauer and Negendank 1993; Felder and Gaupp 2003). Siderite crystals were also found in the interior of frayed, bleached phyllosilicates, which were surrounded by framboidal pyrite and an amorphous organic substance. Relatively low $\delta^{13} \mathrm{C}_{\text {org }}$ values of about $-30 \%$ during this period may be explained, in part, by methanogenesis (Whiticar and Faber 1986; Hollander and Smith 2001), an additional sign of prolonged anoxic conditions.

After 7,000 cal. BP, considerable fluctuations in $\mathrm{Ti}, \mathrm{K}$ and $\mathrm{MS}$ values suggest the onset of higher seasonality with more intense rainfall events in the wet season causing soil erosion and increased fluvial input of minerogenic material (Fig. 3). Lake sedimentation processes switched to a more eventdominated regime in which the observed, graded, minerogenic layers are indicative of single flood events. Individual peaks in these records indicate exceptionally thick, minerogenic flood deposits. Such heavy precipitation events may have been associated with northward shifts of polar fronts (Ledru 1993) or with changing ENSO regimes. Due to underflows generated by these floods, and increasing sediment infill of the lake, bottom waters remained sufficiently oxygenated to prevent the precipitation of siderite and methanogenesis.

The increasing K/Al ratio (Figs. 5, 6) indicates steadily intensified chemical weathering of the parent material in the soils of the catchment under increasingly humid climate and dense forest cover. This is also seen in the increasing $\mathrm{Ca} / \mathrm{Al}$ ratio, 


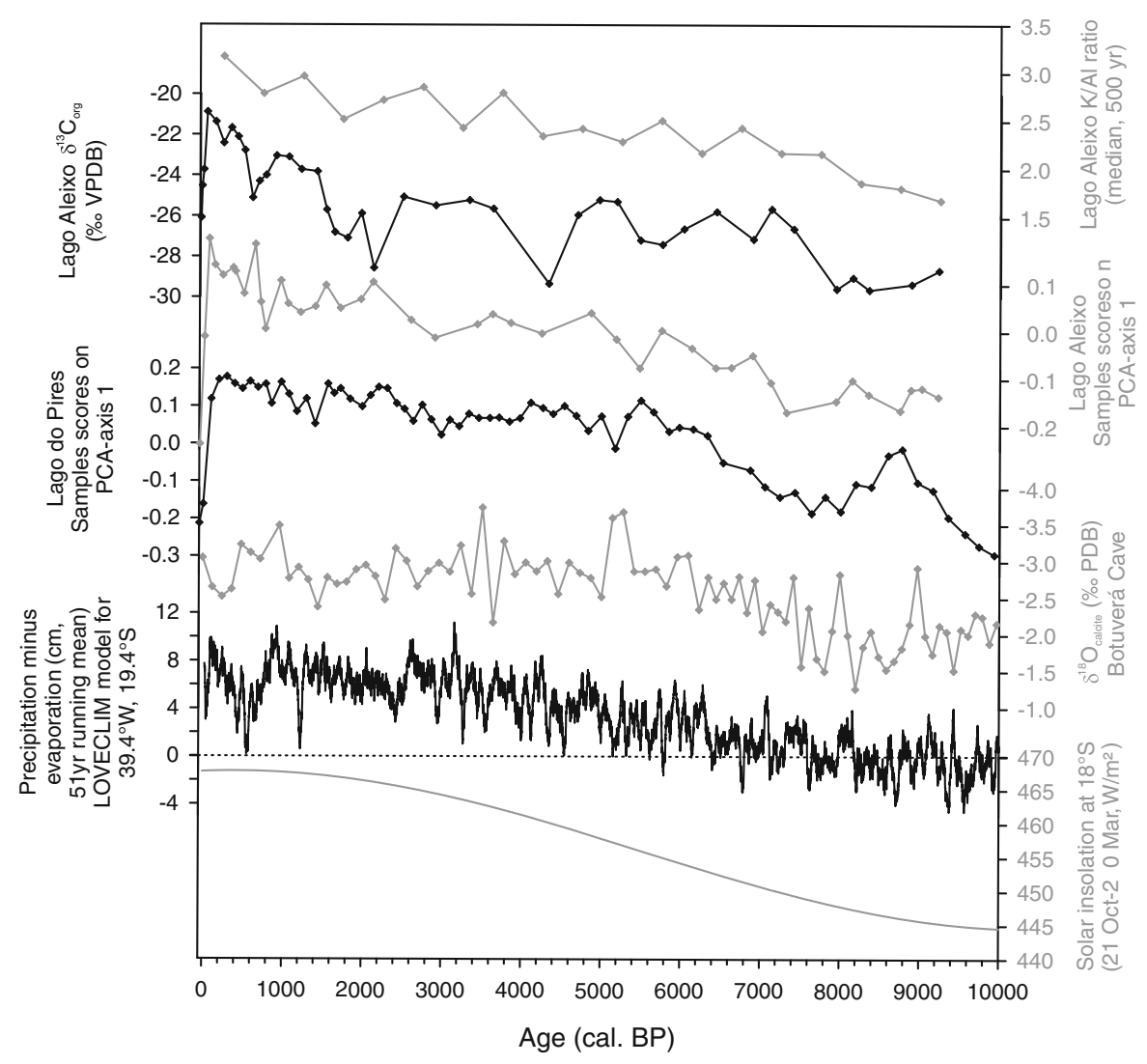

Fig. 6 Comparison of $\mathrm{K} / \mathrm{Al}$ ratios, $\delta^{13} \mathrm{C}_{\mathrm{org}}$ and PCA scores of the pollen record from Lago Aleixo with PCA scores of the pollen record of Lago do Pires (Behling 1995), stalagmite oxygen isotopes from Botuverá Cave, SE Brazil (Cruz et al. 2005), modelled precipitation-evaporation balance (ECBilt-

though the presence of ostracode shells, which contain $\mathrm{CaCO}_{3}$, probably affect this ratio. Increased chemical weathering likely led to the fixation of $\mathrm{Fe}$ in the soils, due to the formation of hydrous oxides, and consequently to a steady decrease of Fe flux into the lake (Fig. 5).

Intensified leaching of base cations may have influenced the availability of nutrients in Lago Aleixo and increased lake primary productivity. This is consistent with peaks in biogenic silica concentrations and the occurrence of Typha in the pollen record. There are, however, three periods characterized by low biogenic silica content $(7,000-5,000$, 2,800-2,000 and 1,500-1,000 cal. BP) during which diatoms were apparently out-competed by other algae, as TOC concentrations do not show similar variability. The relatively low and constant $\mathrm{C} / \mathrm{N}$ ratios $\sim 10.5$ remain close to the average for organic matter
CLIO earth system model of intermediate complexity, Timm and Timmermann 2007), and winter (rainy season) solar insolation for $18^{\circ} \mathrm{S}$ (Laskar et al. 2004). Positive scores on PCA axis 1 are interpreted as more humid conditions

of purely algal origin (Meyers and Lallier-Vergès 1999), but are also in the range of undisturbed cerrado soils (C/N ratios between 8.3 and 10.8, Nascimento et al. 1992) or mixtures between both sources. Evidence for predominance of algal organic matter is provided by the high amounts of biogenic silica, comprising between 10 and $30 \%$ of the total sediment mass. Thus, the increase of $\sim 5 \%$ in the $\delta^{13} \mathrm{C}_{\text {org }}$ values starting at 7,000 cal. BP is most likely related to an increase in lacustrine primary productivity. Due to preferential uptake of ${ }^{12} \mathrm{CO}_{2}$ by primary producers, photosynthesis drives the isotopic composition of the dissolved inorganic carbon $\left(\delta^{13} \mathrm{C}_{\mathrm{DIC}}\right)$ pool of a lake toward a relative enrichment of ${ }^{13} \mathrm{C}$ (Hollander and McKenzie 1991). An increase in lacustrine primary productivity therefore results in progressively more positive $\delta^{13} \mathrm{C}_{\text {DIC }}$ values. These ${ }^{13} \mathrm{C}$-enriched isotope signatures are subsequently 
fixed in algal organic matter, which is sedimented. The observed variations in $\delta^{13} \mathrm{C}_{\text {org }}$ support the previously inferred increase in primary productivity of Lago Aleixo.

Using differences in the $\delta^{13} \mathrm{C}_{\text {org }}$ signature of lacustrine sediments, Sifeddine et al. (2004) reconstructed the changing proportion of $\mathrm{C}_{4}$ and $\mathrm{C}_{3}$ plants in South America and Africa. Plants using the $\mathrm{C}_{4}$ pathway of carbon fixation are adapted to drier conditions with high light intensity and are characterised by relatively high $\delta^{13} \mathrm{C}_{\text {org }}$ values of around -8 to $-15 \%$ (Meyers and Lallier-Vergès 1999). Accordingly, the disappearance of savannah vegetation with a higher proportion of $\mathrm{C}_{4}$ plants should be reflected in decreasing $\delta^{13} \mathrm{C}_{\text {org }}$ values in the sediment. The carbon isotope record of Lago Aleixo, however, shows a trend to less negative values in the latter half of the Holocene despite the fact that pollen evidence suggests closed forests at that time. Expected changes in the proportion of $\mathrm{C}_{4}$ to $\mathrm{C}_{3}$ plants may not be reflected in the $\delta^{13} \mathrm{C}_{\text {org }}$ record of Lago Aleixo due to the predominantly autochthonous source of sediment organic matter. Additionally, the proportion of $\mathrm{C}_{4}$ plants in the surrounding vegetation may have always been negligible, as carbon isotope values of charcoal and soils indicate the predominance of $\mathrm{C}_{3}$ plants during the Holocene in south-eastern Brazil (Pessenda et al. 1996; Gouveia et al. 2002).

After $c a$. 1,000 cal. BP, Ti and $\mathrm{K}$ concentrations drop below average values, indicating that erosion was considerably reduced, probably as a consequence of development of a closed forest cover. During the last century, dramatic increases in magnetic susceptibility, $\mathrm{K}$ and $\mathrm{Ti}$ were accompanied by a rise in herb pollen. These changes illustrate the strong anthropogenic impact of deforestation and consequent soil erosion. During this period, $\mathrm{C} / \mathrm{N}$ ratios increase to around 14 and then drop to 7 in the uppermost sample. This suggests that initial deposits reflected plant debris in topsoils, which is depleted in nitrogen (Kaushal and Binford 1999). Later, more humified organic matter, probably from deeper soil horizons, reached the lake (Farella et al. 2001). Likewise, the decrease in the $\delta^{13} \mathrm{C}_{\text {org }}$ values could reflect increased input of soil organic matter, although detailed studies on the isotopic signatures of possible organic matter sources in the area have not been completed.

\section{Summary and conclusions}

Fossil pollen assemblages and geochemical data from laminated sediments of Lago Aleixo, SE Brazil, indicate that this sediment archive represents a sensitive record of environmental change for tropical South America. Our analyses reveal that increasingly wetter conditions, with a reduced dry period, gradually transformed relatively open savannah vegetation (campo cerrado) with local gallery forests, into a closed semi-deciduous forest. This interpretation is consistent with other records and model data (Fig. 6). Despite a dominance of forest taxa, the vegetation development is mainly reflected in changes of certain ecological groups, such as cerrado species (e.g. Curatella, Stryphenodendron) and taxa from the Atlantic rainforest (Euterpe/Genoma).

The sedimentological analyses complement the environmental changes inferred from the pollen record. They show that the change at about 7,000 cal. BP to moister conditions was accompanied by increased frequency of extreme runoff events, recorded in $\mathrm{K}$ and $\mathrm{Ti}$ records. We interpret high $\mathrm{K}$ concentrations in this tropical lake sediment as reflecting intensified leaching of soils under humid conditions, not as a sign of low lake levels, in contrast to Bush et al. (2002). The most likely cause of increasing $\delta^{13} \mathrm{C}_{\text {org }}$ values in the Late Holocene was an increase in lacustrine primary productivity related to an increased nutrient input by leaching.

Our interpretation of siderite formation differs from the explanation given by Sifeddine et al. (2003) and Rodrigues-Filho et al. (2002). Those authors argued that the formation of secondary siderite occurred during periods of increased humidity and associated dissolution and transport of $\mathrm{Fe}$ into lake basins. At Lago Aleixo, siderite formation does not indicate humid conditions, but rather is indicative of a stratified lake with anoxic bottom water. It is therefore necessary to evaluate the paleoenvironmental significance of the occurrence of siderite in future studies.

These results are generally consistent with nearby records from Lago do Pires and Lagoa Nova (Behling 1995, 2003), however, a dry period between $c a .8,300$ and 6,900 cal. BP detected in both of those records is not recorded in Lago Aleixo (Fig. 6). Although a gap in our record reduced the number of samples for this time period, this difference is probably due to the much larger catchment size of Lago Aleixo compared 
to Lago do Pires and Lagoa Nova. Extensive gallery forest along the tributaries likely concealed vegetation changes of the upland areas, i.e. a return to more open savannah vegetation in the lacustrine pollen spectra of Lago Aleixo. An advantage of the larger catchment size is the possibility to detect intense erosion processes. The deposition of allochthonous material in the lake allowed a complementary environmental reconstruction.

Our study shows that the laminated sediments of Lago Aleixo provide a promising, continuous archive to investigate environmental changes in SE Brazil using a multi-proxy approach. The record provides the potential to study the timing and the responses of the surrounding vegetation to climate changes at high temporal resolution. Such information can contribute to an understanding of the role of the tropics in global climate dynamics (Jennerjahn et al. 2004). Future investigations at Lago Aleixo should include a detailed geochemical characterization of minerogenic and organic matter inputs into the lake as well as a better understanding of the present-day lake system. Furthermore, macrofossil analyses from multiple cores could provide information on the extent of the littoral area and thus evidence of lake level fluctuations. A regional approach, combining records from other lakes with the Lago Aleixo archive, will allow us to distinguish between local and regional signals of climatic change.

Acknowledgments We thank Paulo de Oliveira for assistance during field work, Antje Kappel for help with sample preparation, Ursula Röhl and Thomas Frederichs for the use of sediment logging devices and Andreas Lücke and Holger Wissel for support with carbon isotope analysis. Michael Wille and Steffen Wolters provided helpful comments on earlier drafts of this manuscript. Mark Brenner is acknowledged for editorial help. Parts of this study were financially supported by the National Science Foundation (NSF), BSR-9007019 for field work and the Deutsche Forschungsgemeinschaft (DFG) for pollen analyses.

\section{References}

Behling H (1995) A high resolution Holocene pollen record from Lago do Pires, SE Brazil: vegetation, climate and fire histroy. J Paleolimnol 14:253-268

Behling H (2003) Late glacial and Holocene vegetation, climate and fire history inferred from Lagoa Nova in the southeastern Brazilian lowland. Veg Hist Archaeobot 12:263-270
Behling H, Costa ML (2000) Holocene environmental changes from the Rio Curuá record in the Caxiuanã region, eastern Amazon basin. Quat Res 53:369-377

Brauer A, Negendank JFW (1993) Paleoenvironmental reconstruction of the Late- and postglacial sedimentary record of Lake Weinfelder Maar. In: Negendank JFW, Zolitschka B (eds) Paleolimnology of European maar lakes. Springer, Berlin, pp 223-235

Bush MB, Silman MR (2004) Observations on late Pleistocene cooling and precipitation in the lowland Neotropics. J Quat Sci 19:677-684

Bush MB, Miller MC, Oliveira PED, Colinvaux PA (2002) Orbital forcing signal in sediments of two Amazonian lakes. J Paleolimnol 27:341-352

Cruz FW Jr, Burns SJ, Karmann I, Sharp WD, Vuille M, Cardoso AO, Ferrari JA, Silva Dias PL, Viana O Jr (2005) Insolation-driven changes in atmospheric circulation over the past 116, 000 years in subtropical Brazil. Nature 434:63-66

Cruz FW Jr, Burns SJ, Karmann I, Sharp WD, Vuille M (2006) Reconstruction of regional atmospheric circulation features during the late Pleistocene in subtropical Brazil from oxygen isotope composition of speleothems. Earth Planet Sc Lett 248:494-506

De Oliveira PE (1992) A palynological record of late quaternary vegetational and climatic change in southeastern Brazil. The Ohio State University, Columbus, p 238

Faegri K, Iversen J (1993) Textbook of pollen analysis. Wiley, Chichester, p 328

Farella N, Lucotte M, Louchouarn P, Roulet M (2001) Deforestation modifying terrestrial organic transport in the Rio Tapajós, Brazilian Amazon. Org Geochem 32: 1443-1458

Felder M, Gaupp R (2003) Zur Genese von Sideritanreicherungen in den See-Sedimenten von Baruth, Sachsen (On the genesis of siderite enrichements in the lacustrine sediments of Baruth, Saxony). Zeitschrift geol Wissenschaft 31:313-329

Felfili JM, Fagg CW (2007) Floristic composition, diversity and structure of the "cerrado" sensu stricto on rocky soils in northern Goiás and southern Tocantins, Brazil. Revis Brasil Bot 30:375-385

Garreaud RD, Vuille M, Compagnucci R, Marengo J (2009) Present-day South American climate. Palaeogeogr Palaeoclimatol Palaeoecol 281:180-195

Gouveia SEM, Pessenda LCR, Aravena R, Boulet R, ScheelYbert R, Bendassoli JA, Ribeiro AS, Freitas HA (2002) Carbon isotopes in charcoal and soils in studies of paleovegetation and climate changes during the late Pleistocene and the Holocene in the southeast and centerwest regions of Brazil. Global Planet Change 33:95-106

Heegaard E, Birks HJB, Telford RJ (2005) Relationships between calibrated ages and depth in stratigraphical sequences: an estimation procedure by mixed-effect regression. Holocene 15:612-618

Hollander DJ, McKenzie JA (1991) $\mathrm{CO}_{2}$ control on carbonisotope fractionation during aqueous photosynthesis: a paleo- $\mathrm{pCO}_{2}$ barometer. Geology 19:929-932

Hollander DJ, Smith MA (2001) Microbially mediated carbon cycling as a control on the $\delta^{13} \mathrm{C}$ of sedimentary carbon in eutrophic Lake Mendota (USA): new models for 
interpreting isotopic excursions in the sedimentary record. Geochim Cosmochim Acta 65:4321-4337

IBGE (Instituto Brasileiro de Geografia e Estatística) (1993) Mapa de Vegetação do Brasil, Rio de Janeiro

Jennerjahn TC, Ittekkot V, Arz HW, Behling H, Pätzold J, Wefer G (2004) Asynchronous terrestrial and marine signals of climate change during Heinrich Events. Science 306:2236-2239

Kaushal S, Binford MW (1999) Relationship between C:N ratios of lake sediments, organic matter sources, and historical deforestation in Lake Pleasant, Massachusetts, USA. J Paleolimnol 22:439-442

Laskar J, Robutel P, Joutel F, Gastineau M, Correia ACM, Levrard B (2004) A long-term numerical solution for the insolation quantities of the Earth. Astron Astrophys 428: 261-285

Ledru MP (1993) Late Quaternary environmental and climatic changes in central Brazil. Quat Res 39:90-98

Ledru MP, Behling H, Fournier M, Martin L, Servant M (1994) Positions of the Brazilian Araucaria forest during the Holocene-paleoclimatic implications. CR Acad Sci IIIVie 317:517-521

Lepš J, Šmilauer P (2003) Multivariate analysis of ecological data using CANOCO. Cambridge University Press, Cambridge, p 269

Mayle FE, Burbridge R, Killeen TJ (2000) Millennial-scale dynamics of southern Amazonian rain forests. Science 290:2291-2294

McCune B, Mefford MJ (1999) PC-Ord for windows, multivariate analysis of ecological data, version 4.17. MjM Software, USA

Meyers PA, Lallier-Vergès E (1999) Lacustrine sedimentary organic matter records of Late quaternary paleoclimates. J Paleolimnol 21:345-372

Müller PJ, Schneider R (1993) An automated leaching method for the determination of opal in sediments and particulate matter. Deep-Sea Res 40:425-444

Nascimento VM, Almendros G, Fernandes FM (1992) Soil humus characterisitics in virgin and cleared areas of the Paraná river basin in Brazil. Geoderma 54:137-150

Nimer E (1989) Climatologia do Brasil. Instituto Brasileiro de Geografia e Estatística, Rio de Janeiro, p 421

Olson DM, Dinerstein E, Wikramanayake ED, Burgess ND, Powell GVN, Underwood EC, D'Amico JA, Itoua I, Strand HE, Morrison JC, Loucks CJ, Allnutt TF, Ricketts TH, Kura Y, Lamoreux JF, Wettengel WW, Hedao P, Kassem KR (2001) Terrestrial Ecoregions of the world: a new map of life on earth. Bioscience 51:933-938

Parizzi MG, Salgado-Labouriau ML, Kohler HC (1998) Genesis and environmental history of Lagoa Santa, southeastern Brazil. Holocene 8:311-321

Pereira JAA, Oliveira-Filho AT, Lemos-Filho JP (2007) Environmental heterogeneity and disturbance by humans control much of the tree species diversity of Atlantic montane forest fragments in SE Brazil. Biodivers Conserv 16:1761-1784

Pessenda LCR, Aravena R, Melfi AJ, Telles ECC, Boulet R, Valencia EPE, Tomazello M (1996) The use of carbon isotopes $\left({ }^{13} \mathrm{C},{ }^{14} \mathrm{C}\right)$ in soil to evaluate vegetation changes during the Holocene in central Brazil. Radiocarbon 38:191-201
Reimer PJ, Baillie MGL, Bard E, Bayliss A, Beck JW, Bertrand CJH, Blackwell PG, Buck CE, Burr GS, Cutler KB, Damon PE, Edwards RL, Fairbanks RG, Friedrich M, Guilderson TP, Hogg AG, Hughen KA, Kromer B, McCormac G, Manning S, Ramsey CB, Reimer RW, Remmele S, Southon JR, Stuiver M, Talamo S, Taylor FW, van der Plicht J, Weyhenmeyer CE (2004) IntCal04 terrestrial radiocarbon age calibration, 0-26 Cal Kyr BP. Radiocarbon 46:1029-1058

Rodrigues-Filho S, Müller G (1999) A Holocene sedimentary record from Lake Silvana, SE Brazil-evidence for paleoclimatic changes from mineral, trace-metal und pollen data. Lect Notes Earth Sci 88:1-96

Rodrigues-Filho S, Behling H, Irion G, Müller G (2002) Evidence for lake formation as a response to an inferred Holocene climatic transition in Brazil. Quat Res 57:131137

Salazar LF, Nobre CA, Oyama MD (2007) Climate change consequences on the biome distribution on tropical South America. Geophys Res Lett 34:L09708. doi:09710.01029/ 02007GL029695

Seltzer G, Rodbell D, Burns S (2000) Isotopic evidence for late quaternary climatic change in tropical South America. Geology 28:35-38

Sifeddine A, Martin L, Turcq B, Volkmer-Ribeiro C, Soubiès F, Cordeiro RC, Suguio K (2001) Variations of the Amazonian rainforest environment: a sedimentological record covering 30, 000 years. Palaeogeogr Palaeoclimatol Palaeoecol 168:221-235

Sifeddine A, Spadano Albuquerque AL, Ledru MP, Turcq B, Knoppers B, Martin L, de Mello WZ, Passenau H, Dominguez JML, Cordeiro RC, Abrao JJ, Silva Pinta Bittencourt AC (2003) A 21000 cal years paleoclimatic record from Cacó Lake, northern Brazil: evidence from sedimentary and pollen analyses. Palaeogeogr Palaeoclimatol Palaeoecol 189:25-34

Sifeddine A, Wirrmann D, Spadano Albuquerque AL, Turcq B, Cordeiro RC, Gurgel MHC, Abrão JJ (2004) Bulk composition of sedimentary organic matter used in palaeoenvironmental reconstructions: examples from the tropical belt of South America and Africa. Palaeogeogr Palaeoclimatol Palaeoecol 214:41-53

Stuiver M, Reimer PJ (1993) Extended ${ }^{14} \mathrm{C}$ database and revised CALIB radiocarbon calibration program. Radiocarbon 35:215-230

Timm O, Timmermann A (2007) Simulation of the last 21 000 years using accelerated transient boundary conditions. J Clim 20:4377-4401

Tundisi JG, Saijo Y (1997) Limnological studies on the Rio Doce valley lakes. Brazilian Academy of Sciences, Brazil, p 513

Whiticar MJ, Faber E (1986) Methane oxidation in sediments and water column environments-isotope evidence. Org Geochem 10:759-768

Willis KJ, Araújo MB, Bennett KD, Figueroa-Rangel B, Froyd CA, Myers N (2007) How can a knowledge of the past help to conserve the future? Biodiversity conservation and the relevance of long-term ecological studies. Philos $\mathrm{T}$ Roy Soc B 362:175-186 